\title{
Sigmoid volvulus in pregnancy and puerperium: a surgical and obstetric catastrophe. Report of a case and review of the world literature
}

\author{
Muhammad R Khan ${ }^{*}$ and Sameer ur Rehman
}

\begin{abstract}
Sigmoid volvulus is a rare surgical complication occurring in pregnancy and puerperium. Only 84 cases of sigmoid volvulus in pregnancy have been reported in the English literature so far. We have reviewed the available literature on this subject and present another case recently managed at our institution. The available literature suggests that over the years, there has been an improvement in the maternal and fetal outcome for this critical condition, but delay in presentation and a further delay in diagnosis remain a challenge for the treating physicians. Our patient was a 30-week pregnant lady, who presented late with 6 days history of abdominal pain, distension and absolute constipation. She had evidence of multi-organ dysfunction at presentation due to complicated sigmoid volvulus. She was resuscitated and surgical exploration revealed gangrenous large bowel. Bowel resection with diverting ileostomy was performed, but she succumbed to the septic shock due to late presentation. Acute surgical pathology may be overlooked in pregnant patients due to reluctance in radiological workup and a high index of suspicion is essential for enhanced outcome. There is a need to increase the awareness amongst the obstetricians and general practitioners. Early diagnosis and referral and timely surgical intervention could significantly improve the outcome of this surgical and obstetric catastrophe.
\end{abstract}

Keywords: Sigmoid volvulus, Pregnancy, Outcome

\section{Background}

Sigmoid volvulus in pregnancy is a rare but serious complication associated with a significant maternal and fetal mortality [1]. The fundamental problem of sigmoid volvulus in pregnancy is that of delay in presentation and further delay in diagnosis leading to ischemia of the colon, which requires bowel resection and colostomy as seen in most of the reported cases [2-20]. Timely surgical intervention is essential to reduce maternal and fetal morbidity and mortality [1]. Perforation, peritonitis and sepsis can be the maternal complications if intervention is not done early in the course of the disease. The fetal complications include preterm delivery, intrauterine death and neonatal sepsis. We have reviewed the available literature on this subject and report another case of a 30-week pregnant lady who presented to us with complicated sigmoid volvulus (Table 1). There is a need to

\footnotetext{
* Correspondence: khan.rizwan@aku.edu

Department of Surgery and Medical College, Aga Khan University \& Hospital, Stadium Road, Karachi, 74800, Pakistan
}

increase the awareness amongst the general practitioners and community obstetricians for this potentially life threatening condition. A high index of suspicion and judicious use of modern radiological imaging may help make an early diagnosis and improve the maternal and fetal outcomes.

\section{Case presentation}

A 25-year-old pregnant lady, gravida 2 and para 1, presented to the emergency room with 6 days history of lower abdominal pain, abdominal distension, bilious vomiting and constipation. She had no significant past medical or surgical history and her menstrual and antenatal history were uneventful. She was being managed conservatively for these complaints at a local hospital before presenting to us in the emergency. On examination, she was dehydrated, tachycardiac with a heart rate of 136 beats per minute and tachypneic with a respiratory rate of 28 per minute. Her initial blood pressure was $102 / 69 \mathrm{mmHg}$ and she was drowsy. Her abdomen 
Table 1 Reported Cases of Sigmoid Volvulus in Pregnancy and Puerperium

\begin{tabular}{|c|c|c|c|c|c|c|c|c|}
\hline \multirow[t]{2}{*}{ Authors } & \multirow{2}{*}{$\begin{array}{l}\text { Year of } \\
\text { the study }\end{array}$} & \multirow{2}{*}{$\begin{array}{l}\text { Number } \\
\text { of cases } \\
\text { reported }\end{array}$} & \multirow{2}{*}{$\begin{array}{l}\text { Stage of } \\
\text { pregnancy } \\
\text { in weeks }\end{array}$} & \multirow{2}{*}{$\begin{array}{l}\text { Duration of } \\
\text { symptoms } \\
\text { in days }\end{array}$} & \multirow{2}{*}{$\begin{array}{l}\text { Status } \\
\text { of colon }\end{array}$} & \multirow[t]{2}{*}{ Treatment offered } & \multicolumn{2}{|c|}{ Outcome } \\
\hline & & & & & & & Mother & Fetus \\
\hline Recent Cases & $1978-2011$ & 20 & & & & & & \\
\hline Present case & 2011 & 1 & 30 & 6 days & Gangrenous & $\begin{array}{l}\text { Total colectomy with } \\
\text { proximal ileostomy }\end{array}$ & Expired & IUD \\
\hline \multirow[t]{4}{*}{ Kolusari A et al [2] } & 2009 & 4 & 7 & 1 & Gangrenous & $\begin{array}{l}\text { Resection of sigmoid colon } \\
\text { with primary anastomosis }\end{array}$ & Healthy & Alive \\
\hline & & & 31 & 2 & Gangrenous & $\begin{array}{l}\text { Resection of sigmoid colon } \\
\text { with proximal colostomy }\end{array}$ & Healthy & IUD \\
\hline & & & 32 & 2 & Gangrenous & $\begin{array}{l}\text { Resection of sigmoid colon } \\
\text { with proximal colostomy }\end{array}$ & Healthy & Alive \\
\hline & & & Puerperium & 3 & Gangrenous & $\begin{array}{l}\text { Resection of sigmoid colon } \\
\text { with proximal colostomy }\end{array}$ & Expired & Alive \\
\hline Vo TM et al [3] & 2008 & 1 & 28 & 1 & Gangrenous & $\begin{array}{l}\text { Resection of sigmoid colon } \\
\text { with proximal colostomy }\end{array}$ & Healthy & Alive \\
\hline Iwamoto I et al [4] & 2007 & 1 & 35 & 3 & Perforated & $\begin{array}{l}\text { Repair of perforation with } \\
\text { proximal colostomy }\end{array}$ & Expired & IUD \\
\hline $\begin{array}{l}\text { Sascha Dua R } \\
\text { et al [5] }\end{array}$ & 2007 & 1 & Puerperium & 1 & Viable & Laparotomy and sigmoidopexy & Healthy & Alive \\
\hline $\begin{array}{l}\text { Machado NO } \\
\text { et al [6] }\end{array}$ & 2006 & 1 & 18 & 1 & Viable & $\begin{array}{l}\text { Resection of sigmoid colon } \\
\text { with primary anastomosis }\end{array}$ & Healthy & Alive \\
\hline Alshawi JS [7] & 2005 & 1 & $\begin{array}{l}28 \& 35 \\
\quad \text { (recurrent) }\end{array}$ & 1 & Viable & $\begin{array}{l}\text { Sigmoidoscopy and decompression } \\
\text { followed by elective sigmoid } \\
\text { colectomy }\end{array}$ & Healthy & Alive \\
\hline De $U$ et al $[8]$ & 2005 & 1 & 24 & 3 & Gangrenous & $\begin{array}{l}\text { Resection of sigmoid colon } \\
\text { with proximal colostomy }\end{array}$ & Healthy & IUD \\
\hline Joshi MA et al [9] & 1999 & 1 & 28 & 2 & Gangrenous & $\begin{array}{l}\text { Resection of sigmoid colon } \\
\text { with proximal colostomy }\end{array}$ & Healthy & IUD \\
\hline Lurie $S$ et al [10] & 1997 & 1 & $\begin{array}{l}\text { Ectopic } \\
\text { Pregnancy }\end{array}$ & 2 & Viable & $\begin{array}{l}\text { Laparotomy and de-torsion } \\
\text { of volvulus }\end{array}$ & Healthy & Ectopic \\
\hline Lord SA et al [11] & 1996 & 1 & 36 & 2 & Gangrenous & $\begin{array}{l}\text { Resection of sigmoid colon } \\
\text { with proximal colostomy }\end{array}$ & Healthy & Alive \\
\hline Allen JC [12] & 1990 & 1 & 28 & 1 & Viable & Sigmoidoscopy and decompression & Healthy & Alive \\
\hline $\begin{array}{l}\text { Keating JP } \\
\quad \text { et al [13] }\end{array}$ & 1985 & 1 & 34 & 1 & Viable & $\begin{array}{l}\text { Resection of sigmoid colon } \\
\text { with double barrel colostomy }\end{array}$ & Healthy & Alive \\
\hline \multirow[t]{2}{*}{$\begin{array}{r}\text { Hofmeyr GJ } \\
\text { et al [14] }\end{array}$} & 1985 & 2 & 33 & 3 & Gangrenous & $\begin{array}{l}\text { Resection of sigmoid colon } \\
\text { with proximal colostomy }\end{array}$ & Healthy & IUD \\
\hline & & & 26 & 3 & Gangrenous & $\begin{array}{l}\text { Resection of sigmoid colon } \\
\text { with proximal colostomy }\end{array}$ & Expired & IUD \\
\hline Fraser JL et al [15] & 1983 & 1 & 32 & 1 & Viable & $\begin{array}{l}\text { Laparotomy and de-torsion } \\
\text { of volvulus }\end{array}$ & Healthy & Alive \\
\hline Fuller JK et al [16] & 1978 & 1 & Puerperium & 1 & Viable & $\begin{array}{l}\text { Laparotomy and de-torsion } \\
\text { of volvulus }\end{array}$ & Healthy & Alive \\
\hline Lazaro EJ et al [17] & $1958-1969$ & 13 & & & & & & \\
\hline $\begin{array}{r}\text { Harer WB Jr. } \\
\text { et al [18] }\end{array}$ & $1944-1958$ & 11 & & & & & & \\
\hline Kohn SG et al [19] & $1931-1944$ & 12 & & & & & & \\
\hline Lambert AC [20] & Before 1931 & 29 & & & & & & \\
\hline
\end{tabular}

was distended and tense, with generalized tenderness and a tympanitic note on percussion. The uterine size was of 30 weeks gestation. Rectal examination revealed no stool and cervical os was closed on per vaginal examination. She was clinically suspected to have peritonitis with evidence of septic shock. She was resuscitated with intravenous fluids and antibiotics.

Plain radiographs of the chest and abdomen showed pneumoperitoneum, a single fetus and a distended gas filled transverse colon. Ultrasound scan of the abdomen 
revealed moderate amount of free fluid with mobile internal echoes representing bowel content and intrauterine death of the fetus. Her laboratory workup revealed severe electrolyte imbalance with serum potassium of $6.3 \mathrm{mmol} / \mathrm{L}$ (normal 3.5-5) and blood glucose level of $39 \mathrm{mg} / \mathrm{dL}$ (normal 80-160). She had evidence of severe metabolic acidosis with serum $\mathrm{pH}$ of 7.18 (normal 7.36-7.44), hypoxia with pO2 of $39 \mathrm{mmHg}$ (normal 85$105)$ and deranged coagulation. The surgical and obstetric teams in the emergency room evaluated the patient. While being resuscitated in the emergency room, the conscious level of the patient dropped further and she was intubated and put on the mechanical ventilator.

With the clinical diagnosis of bowel perforation and peritonitis, the patient was taken up for emergency laparotomy. Intra-operatively findings were of sigmoid volvulus resulting in closed loop obstruction leading to distension and ischemia of whole large bowel. The whole of the colon was dilated, friable, and gangrenous. Multiple perforations were identified in the colon with around $800 \mathrm{ml}$ of feculent material aspirated on opening the abdomen. Whole colon was mobilized \& resected and diverting ileostomy with a Hartman's procedure was done. A lower segment caesarean section was done for delivering the dead fetus and modified B-lynch sutures applied to the uterus. Post-operatively, she was continued on broad-spectrum antibiotics and shifted to the intensive care unit. She had an initial period of recovery for a couple of days, but subsequently, her pulmonary function deteriorated with development of pneumonia and adult respiratory distress syndrome. In addition to high ventilator support, she also needed increasing dose of inotropes and eventually expired on the $8^{\text {th }}$ post-operative day due to overwhelming sepsis and organ dysfunction.

\section{Discussion}

The incidence of intestinal obstruction in pregnancy ranges from 1 in 1500 to 1 in 66431 deliveries [2]. Intestinal obstruction in pregnancy can be caused by many factors including congenital or postoperative adhesions, volvulus, intussusceptions, hernia and appendicitis [1]. Sigmoid volvulus is the most common cause of bowel obstruction complicating pregnancy, accounting for up to 44 per cent of cases [21]. Pregnancy itself is considered to be the precipitating factor for sigmoid volvulus. The occurrence of sigmoid volvulus in pregnancy is due to displacement, compression and partial obstruction of a redundant or abnormally elongated sigmoid colon by the gravid uterus [18]. This could probably explain the increased incidence of sigmoid volvulus in the third trimester of pregnancy [1]. Despite this higher propensity in the third trimester, there have been reports of this complication developing in the early pregnancy as well as the puerperium $[2,5,16,18]$.
To date, 84 cases of sigmoid volvulus have been reported occurring in the pregnancy and puerperium (Table 1). Lambert [20] reported 29 cases of sigmoid volvulus before 1931, followed by another 12 cases reported by Kohn et al [19] between 1931 and 1944. Subsequently, all the previously reported cases were reviewed by Harer et al [18] in 1958, who reported an additional 11 cases between 1994 and 1958. Later on, Lazaro et al [17] compiled another 13 cases occurring between 1558 and 1969. In this report, we have identified 19 more cases reported till 2009, and include another case managed recently at our institution.

The diagnosis of sigmoid volvulus is suspected when a pregnant female presents with a clinical triad of abdominal pain, distention, and absolute constipation. The average time from the onset of obstructive symptoms until presentation has been reported to be 48 hours [1]. This is largely because pregnancy itself masks the clinical picture since abdominal pain, nausea, and leukocytosis can occur in an otherwise normal course of pregnancy [13]. In our review of recent 20 cases, the mean delay between the onset of symptoms to presentation was 2 days, with a range from few hours to as many as 6 days, as seen in our case. Six patients presented more than 48 hours after the onset of symptoms. Harer et al [18] also noted similar delay in presentation in their review and concluded that such a delay in diagnosis and surgical intervention had a significant impact on the ultimate outcome of the mother and fetus.

The maternal and fetal outcome in sigmoid volvulus has been directly related to the degree of bowel ischemia and subsequent systemic sepsis. In our analysis of recent 20 cases, there were $4(20 \%)$ maternal and 8 (40\%) fetal deaths, including one ectopic pregnancy. It is important to note that all the maternal deaths occurred in the group of patients where delay in presentation and surgical intervention was more than 2 days. $[2,4,14]$ Similarly, 5 fetal deaths were seen in patients who presented after 48 hours of onset of symptoms, as compared to 2 fetal deaths in patients presenting early in the course of the disease. This observation highlights the fact that high index of clinical suspicion is vital in cases of intestinal obstruction in pregnant patients. This facts needs to be emphasized amongst the general practitioners and community obstetricians primarily responsible for taking care of these patients.

Another important area of concern is the reluctance in the utilization of modern radiological diagnostic tools in pregnant patients. There have always been concerns about the radiation exposure of the fetus during pregnancy. Significant radiation exposure may lead to chromosomal mutations, neurologic abnormalities, mental retardation, and increased risk of childhood leukemia. Cumulating radiation dosage is the primary risk factor for adverse fetal 
effects, but fetal age at exposure is also important [22-24]. Exposure during the first week of gestation results in highest rates of fetal mortality. The next most sensitive time period is between 10 and 17 weeks of gestation, when central nervous system teratogenesis becomes an important consideration. After this period, the concern shifts from teratogenesis to the risk of childhood hematologic malignancy. It has been recommended that the cumulative radiation dose to the fetus during pregnancy should be less than 5-10 rads [25]. In general, no single diagnostic study exceeds 5 rads of radiation exposure. As an example, the radiation dose to the fetus for a plain abdominal radiograph averages $0.1-0.3$ rads, while a CT of the pelvis and abdomen yields up to 5 rads of fetal exposure [26]. In any case, the health and life of the mother takes priority over the concerns for the fetus and judicious use of radiation may help make an early diagnosis with optimal outcome for both the mother and the fetus.

The management of intestinal obstruction and perforation in pregnant women is pretty much similar to that of non-pregnant women. The basis of therapy is early surgical intervention [27]. Surgery should be performed via midline vertical laparotomy. In the third trimester, if sufficient intestinal exposure cannot be obtained due to enlarged uterus, a caesarean section must be carried out [28]. The entire bowel should be examined for other areas of obstruction. Intestinal viability should be assessed cautiously and segmental resection with or without anastomosis is often necessary [27].

\section{Conclusions}

Sigmoid volvulus complicating pregnancy is very rare condition with significant maternal and fetal morbidity and mortality. Timely diagnosis mandates high index of clinical suspicion in patients presenting with abdominal pain, distension and absolute constipation. Hesitancy in getting $\mathrm{X}$-rays in view of pregnant situation must be avoided and appropriate management must be defined. Delay in diagnosis and treatment beyond 48 hours results in increased fetal and maternal morbidity and mortality. Review of the available literature emphasizes the importance of early diagnosis and timely intervention to minimize maternal and fetal morbidity and mortality.

\section{Consent}

A written informed consent was obtained from the next of kin of the patient for publication of this Case report and any accompanying images. A copy of the written consent is available for review by the Editor-in-Chief of this journal.

\section{Competing interests}

The author declares that they have no competing interest.

\section{Authors' contribution}

MRK conceived the study. SR collected the data and prepared the initial manuscript. The manuscript was critically reviewed and approved by all the authors.

Received: 7 February 2012 Revised: 19 February 2012

Accepted: 24 April 2012 Published: 02 May 2012

\section{References}

1. Perdue PW, Johnson HW Jr, Stafford PW: Intestinal obstruction complicating pregnancy. Am J Surg 1992, 164:384-388.

2. Kolusari A, Kurdoglu M, Adali E, Yildizhan R, Sahin HG, Kotan C: Sigmoid volvulus in pregnancy and puerperium: a case series. Cases Journal 2009, 2:9275.

3. Vo TM, Gyaneshwar R, Mayer C: Concurrent sigmoid volvulus and herniation through broad ligament defect during pregnancy: case report and literature review. J Obstet Gynaecol Res 2008, 34:658-662.

4. Iwamoto I, Miwa K, Fujino T, Douchi T: Perforated colon volvulus coiling around the uterus in a pregnant woman with a history of severe constipation. J Obstet Gynaecol Res 2007, 33:731-733.

5. Sascha Dua R, Rothnie ND, Gray EA: Sigmoid volvulus in the Puerperium. Int J Gynaecol Obstet 2007, 97:195.

6. Machado NO, Machado LS: Sigmoid volvulus complicating pregnancy managed by resection and primary anastomosis; case report with literature review. Sultan Qaboos Univ Med J 2009, 9:84-88.

7. Alshawi JS: Recurrent sigmoid volvulus in pregnancy: report of a case and review of the literature. Dis Colon Rectum 2005, 48:1811-1813.

8. De U, De KK: Sigmoid volvulus complicating pregnancy. Indian J Med Sci 2005, 59:317-319.

9. Joshi MA, Balsarkar D, Avasare N, Pradhan C, Pereira G, Subramanyan P, et al: Gangrenous sigmoid colon in a pregnant woman. Trop Gastroenterol 1999, 20:141-142.

10. Lurie S, Katz Z, Rabinerson D, Simon D: Sigmoid volvulus after medical management with subsequent operative laparoscopy of unruptured ectopic pregnancy. Gynecol Obstet Invest 1997, 43:204-205.

11. Lord SA, Boswell WC, Hungerpiller JC: Sigmoid volvulus in pregnancy. Am Surg 1996, 62:380-382.

12. Allen JC: Sigmoid volvulus in pregnancy. J R Army Med Corps 1990, 136:55-56.

13. Keating JP, Jackson DS: Sigmoid volvulus in late pregnancy. $J$ R Army Med Corps 1985, 131:72-74

14. Hofmeyr GJ, Sonnendecker EW: Sigmoid volvulus in advanced pregnancy. Report of 2 cases. S Afr Med J 1985, 67:63-64.

15. Fraser $J$, Eckert LA: Volvulus complicating pregnancy. Can Med Assoc J 1983, 128:1045-1048.

16. Fuller JK, Larrieu AJ: Sigmoid volvulus in the young: a case following cesarean section. Arch Surg 1978, 113:316-317.

17. Lazaro EJ, Das PB, Abraham PV: Volvulus of the sigmoid colon complicating pregnancy. Obstet Gynecol 1969, 33:553-557.

18. Harer WB Jr, Harer WB Sr: Volvulus complicating pregnancy and puerperium; report of three cases and review of literature. Obstet Gynecol 1958, 12:399-406

19. Kohen SG, Briele HA, Douglas LH: Volvulus in pregnancy. Am J Obst \& Gynec 1944, 48:398.

20. Lambert AC: Paris thesis.: ; 1931.

21. Ballantyne $\mathrm{GH}$, Brandner MD, Beart RW Jr, Ilstrup DM: Volvulus of the colon. Incidence and mortality. Ann Surg 1985, 202:83-92.

22. Kennedy A: Assessment of acute abdominal pain in the pregnant patient Semin Ultrasound CT MR 2000, 21:64-77.

23. Toppenberg KS, Hill DA, Miller DP: Safety of radiographic imaging during pregnancy. Am Fam Physician 1999, 59:1813-1818.

24. Timins JK: Radiation during pregnancy. N J Med 2001, 98:29-33.

25. Karam PA: Determining and reporting fetal radiation exposure from diagnostic radiation. Health Phys 2000, 79:585-590.

26. Chen MM, Coakley FV, Kaimal A, Laros RK Jr: Guidelines for computed tomography and magnetic resonance imaging use during pregnancy and lactation. Obstet Gynecol 2008, 112:333-340. 
27. Allen JR, Helling TS, Langenfeld M: Intraabdominal surgery during pregnancy. Am J Surg 1989, 158:567-569.

28. Redlich A, Rickes S, Costa SD, Wolff S: Small bowel obstruction in pregnancy. Arch Gynecol Obstet 2007, 275:381-383.

doi:10.1186/1749-7922-7-10

Cite this article as: Khan and Rehman: Sigmoid volvulus in pregnancy and puerperium: a surgical and obstetric catastrophe. Report of a case and review of the world literature. World Journal of Emergency Surgery 2012 7:10

\section{Submit your next manuscript to BioMed Central} and take full advantage of:

- Convenient online submission

- Thorough peer review

- No space constraints or color figure charges

- Immediate publication on acceptance

- Inclusion in PubMed, CAS, Scopus and Google Scholar

- Research which is freely available for redistribution 